Abstracta Iranica Abstracta Iranica

Revue bibliographique pour le domaine irano-aryen

Volume 23 | 2002

Comptes rendus des publications de $\mathbf{2 0 0 0}$

\title{
« Four Bactrian Economic Documents». Bulletin of the Asia Institute, 11, (1996 ; [2000]), pp. ;3-15
}

\section{Étienne de La Vaissière}

\section{(2) OpenEdition}

10 Journals

\section{Édition électronique}

URL : http://journals.openedition.org/abstractairanica/35154

DOI : 10.4000/abstractairanica.35154

ISSN : 1961-960X

Éditeur :

CNRS (UMR 7528 Mondes iraniens et indiens), Éditions de l'IFRI

\section{Édition imprimée}

Date de publication : 15 mai 2002

ISSN : 0240-8910

\section{Référence électronique}

Étienne de La Vaissière, « «Four Bactrian Economic Documents». Bulletin of the Asia Institute, 11, (1996 ; [2000]), pp. ;3-15», Abstracta Iranica [En ligne], Volume 23 | 2002, document 26, mis en ligne le 08 février 2010, consulté le 25 septembre 2020. URL : http://journals.openedition.org/abstractairanica/ 35154 ; DOI : https://doi.org/10.4000/abstractairanica.35154

Ce document a été généré automatiquement le 25 septembre 2020.

Tous droits réservés 


\section{« Four Bactrian Economic Documents». Bulletin of the Asia Institute, 11, (1996; [2000]), pp. ;3-15}

Étienne de La Vaissière

L'A. traduit et commente philologiquement de courts documents économiques bactriens, en avant-première de sa grande édition, parue dans le Corpus Inscriptionum Iranicarum (voir c.r. $n^{\circ} 25$ ) : deux reçus pour des prêts de grains, de farine, de vin..., un reçu pour un prêt en pièces d'or, et une liste de bétail réquisitionné. L'article est utile en ce qu'il donne un commentaire philologique et des photos qui ne seront publiés que dans les volumes suivants du Corpus. Pour la traduction, en revanche, on se réfèrera au premier volume paru dans le Corpus, qui donne des textes améliorés.

\section{INDEX}

Thèmes : 2.1. Langues anciennes

\section{AUTEURS}

ÉTIENNE DE LA VAISSIÈRE

ENS - Paris 